\title{
RELATIONSHIP BETWEEN ARBOREAL, TOPOGRAPHIC, AND EDAPHIC STRUCTURES IN A STRETCH OF A RIPARIAN FOREST IN THE PAMPA BIOME, RIO GRANDE DO SUL, BRAZIL
}

\author{
Ana Claudia Bentancor Araujo ${ }^{1 *}$, Helio Junior Bentancor Araujo ${ }^{2}$,Edenir Luis Grimm ${ }^{3}$, Solon Jonas Longhi ${ }^{4}$ \\ ${ }^{1}$ Farroupilha Federal Institute/Campus Alegrete, Alegrete, Rio Grande do Sul, Brazil - ana.araujo@iffarroupilha.edu.br \\ ${ }^{2}$ Farroupilha Federal Institute/Campus Sant'Ana do Livramento, Sant'Ana do Livramento, Rio Grande do Sul, Brazil - \\ bentancorhelinho@gmail.com \\ ${ }^{3}$ Farroupilha Federal Institute/Campus Alegrete, Alegrete, Rio Grande do Sul, Brazil - edenir.grimm@iffarroupilha.edu.br \\ ${ }^{4}$ Federal University of Santa Maria, Graduate Program in Forestry Engineering, Santa Maria, Rio Grande do Sul, Brazil - \\ longhi.solon@gmail.com \\ Received for publication: 29/04/2018 - Accepted for publication: 14/12/2018
}

\begin{abstract}
Resumo
Relação entre a estrutura arbórea, topografica e edáfica em um trecho de floresta ribeirinha no bioma Pampa, RS, Brasil. No bioma Pampa, com consideráveis perdas de área natural, o número de estudos científicos em áreas florestais ainda é pequeno e menor ainda quando se trata da regeneração natural desses ambientes. Sendo assim, a presente pesquisa objetivou analisar a estrutura arbóreo-arbustiva e regenerante e, a influência das variáveis ambientais na distribuição das espécies em um trecho de floresta ribeirinha do arroio Espinilho, bioma Pampa, Rio Grande do Sul. O componente arbóreo-arbustivo foi avaliado em 100 parcelas $(10 \mathrm{~m} \times 10 \mathrm{~m})$ instaladas sistematicamente no interior da floresta e para avaliar o componente regenerante estabeleceram-se duas classes: Classe I (indivíduos com $10 \mathrm{~cm} \leq \mathrm{h}<1 \mathrm{~m}$ ), avaliada em subunidades de $2 \mathrm{~m} \times 2 \mathrm{~m}$ e Classe II (indivíduos com $\mathrm{DBH}<5 \mathrm{~cm} \mathrm{e} \mathrm{h} \geq 1 \mathrm{~m}$ ), avaliadas em subunidades de 5 $\mathrm{m} \times 5 \mathrm{~m}$. No estrato arbóreo-arbustivo, as espécies mais importantes foram Ocotea acutifolia (Nees) Mez e Pouteria salicifolia (Spreng.) Radlk. e na regeneração natural foram Eugenia uniflora L. e Blepharocalyx salicifolius (Kunth) O.Berg. As características do relevo, do solo e do dossel condicionaram as espécies do estrato arbóreo-arbustivo e regenerante. O estádio regenerante das espécies foi condicionado por variáveis distintas das relacionadas ao componente arbóreo.
\end{abstract}

Palavras-chave: fitossociologia, regeneração natural, Campanha Gaúcha.

\begin{abstract}
Despite the considerable loss of natural area in the Pampa biome, the number of scientific studies carried out here is low; it is lower in terms of natural regeneration. Therefore, the present study analyzed arboreal shrub and natural regeneration as well as the influence of environmental variables on the distribution of a riverine forest of the Espinilho stream in the Pampa biome, Rio Grande do Sul. A hundred plots were systematically set for arboreal shrub sampling. To evaluate the regenerating component, two classes were established: Class I and Class II. The main species in the arboreal shrub were Ocotea acutifolia (Nees) Mez and Pouteria salicifolia (Spreng.) Radlk., while those in natural regeneration were Eugenia uniflora L. and Blepharocalyx salicifolius (Kunth) O.Berg. The characteristics of the relief, soil, and canopy conditioned the species of the arboreal shrub and regenerating strata.

Keywords: phytosociology, natural regeneration, Campanha Gaúcha.
\end{abstract}

\section{INTRODUCTION}

The Pampa biome is the second smallest biome in Brazil, and one of the most scarcely scientifically studied (KILCA et al., 2012; OLIVEIRA et al., 2015). According to Vélez et al. (2009), there is a need to create inventories of its biodiversity as well as to periodically monitor its vegetation cover to increase the knowledge and appreciation of the biome.

The vegetation in this biome is predominantly rural, with a few forest regions; these occupy the areas of the crystalline shield of the Rio Grande and countryside (Campanha) plateau (OLIVEIRA et al., 2015). Forests are also found along large water courses, where they are limited to narrow cords or bands of variable width depending on the characteristics of the relief, and are generally embedded in the rolling valleys.

Some studies were performed in the riverside forests of Rio Grande do Sul by physiognomic, floristic, and ecological approaches. Budke et al. (2010) studied the effects of flooding on the soil characteristics and structure of a forest located in the central region of the state. Araujo et al. (2016) analyzed the effects of anthropic disturbances of different intensities on the structure of the tree bush component in two stretches of a riparian forest in the Campanha Gaúcha region of the Pampa biome. Oliveira et al. (2015) described the effect of 
the topographic and soil characteristics on the abundance and distribution of the species in a riparian forest located in the Campanha Gaúcha region of the Pampa biome.

In regard to the Pampa, despite the considerable losses of natural areas, the number of scientific studies conducted on forest areas is still small; it is smaller for the natural regeneration of these environments. However, a comparison of the arboreal physiognomy of the degraded areas relative to the forest covered areas makes it possible to understand the mechanisms of the changes in the floristic composition and structure occurring in secondary succession. Therefore, including the regenerating component in research is important because natural regeneration initiates forest restoration after natural or anthropic disturbances (SILVA et al., 2010).

The purpose of this study is to describe the phyto-sociological aspects of the arboreal shrub and regenerating components and investigate the relationship between the environmental variables and ordering of the species in a stretch of a riverine forest in the Espinilho stream in the Pampa biome. The formulated hypothesis is that there are variations in the ordering of the species along the environmental gradient of an evaluated forest, as a function of the soil, canopy, and topography.

\section{MATERIAL AND METHODS}

The section of the evaluated forest is located in the middle course of the Espinilho stream (30 $52^{\prime} 44^{\prime \prime} \mathrm{S}$

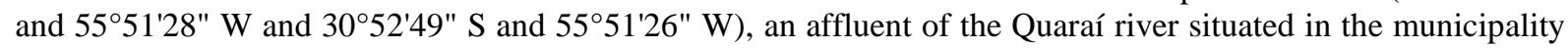
of Sant'Ana do Livramento, Rio Grande do Sul, Brazil.

The study area belongs to the physiographic region of Campanha, located southwest of Rio Grande do Sul. This region has sufficient dominance of litholic neosols or eutrophic regolytics (pedregal unit), typically located in soft undulating reliefs and also in areas with a strong undulating relief, in association with rock outcrops (STRECK et al., 2008).

This region is predominated by a rural landscape, with forest formations in the drainage areas between undulations, on the slopes and board bases, and along the rivers (OLIVEIRA et al., 2015). The forest formations in the region are classified as deciduous seasonal forests, complementing the riparian areas according to Rodrigues (2009), such as the deciduous riverine seasonal forests.

The climate of the region is classified as humid subtropical, with no defined dry season, and hot summers. The average annual temperature is $17.8{ }^{\circ} \mathrm{C}$, and the average annual pluviometric precipitation is approximately 1,700 mm (MATZENAUER et al., 2011).

For the vegetation sampling, systematic and perpendicular ranges were allocated to the stream bank. The distance between the strips was $50 \mathrm{~m}$ with a width of $10 \mathrm{~m}$, and each strip was divided into $10 \mathrm{~m} \times 10 \mathrm{~m}$ plots. A total of 100 plots were demarcated (I range: 4; II range: 7; III range: 9; IV range: 9; V range: 13; VI range: 11; VII range: 11; VIII range: 14 and IX range: 22), totaling 1 ha of the sampled area. The length of the strips varied according to the width of the forest, and the strips were arranged sequentially to sample the dyke, middle, and edge of the forest. Specimens with a diameter at breast height (DBH) $\geq 5 \mathrm{~cm}$ were included in the tree bush layer. The data for this component were collected in January and February 2015.

Within the $10 \mathrm{~m} \times 10 \mathrm{~m}$ plots, subunits were created to assess natural regeneration. Two classes were established for the evaluation of this component: Class I: specimens with $10 \mathrm{~cm} \leq \mathrm{h}<1 \mathrm{~m}$, and Class II: specimens with BHD $<5 \mathrm{~cm}$ and $\mathrm{h} \geq 1 \mathrm{~m}$. Class I was evaluated in subunits of $2 \mathrm{~m} \times 2 \mathrm{~m}$, and Class II was sampled in subunits of $5 \mathrm{~m} \times 5 \mathrm{~m}$. Natural regeneration was sampled in March and June 2015. For each specimen of the arboreal shrub component, the CBH was measured, and the circumference was obtained at 1.30 $\mathrm{m}$ of soil height, in addition to the total height. For the classes of natural regeneration, the total heights of the specimens were measured, and for Class II regeneration, $\mathrm{CBH}$ was also measured, when the specimen had a height longer than $1.30 \mathrm{~m}$. The measured $\mathrm{CBH}$ values were subsequently converted into the BHD.

The identification was performed in loco at the species level, and the vegetative material of the unidentified specimens was collected for subsequent identification. The identification was achieved using specialists, bibliographies, and comparison with the material already identified in the Herbarium collection of the Department of Forest Sciences (HDFS) of the Federal University of Santa Maria (FUSM). The species were classified within the families recognized by the Angiosperm Phylogeny Group IV system (BYNG et al., 2016), and the confirmation of the scientific nomenclature was based on Flora do Brasil 2020.

In the study, the used environmental variables included topographic characteristics (slope and elevation), canopy opening, soil characteristics, soil moisture, and thickness of the litter.

The slope, in degrees, was measured with the aid of an electronic hypsometer, Vertex VI, which was applied to all the plots.

The altitude quota, in meters, was obtained in the center of each plot, using the Global Positioning System (GPS). 
A Dutch auger and a ruler were used to obtain the depth of the soil, and a $10 \mathrm{~m} \times 10 \mathrm{~m}$ perforation was made in the center of each plot. When the depth change was extremely abrupt between two plots, another boring was performed within the unit, yielding the average depth of the soil.

Within the $10 \mathrm{~m} \times 10 \mathrm{~m}$ plots, the thickness of the accumulated organic matter was measured at three random points, yielding the arithmetic mean for each plot.

For the determination of the physical and chemical soil characteristics, 50 compost samples were collected. Each sample was formed by five sub-samples at a depth of 0-20 cm, collected by the Dutch auger.

For the chemical analysis of the soil, the samples were sent to the Soil Analysis Laboratory of the Federal University of Santa Maria. The variables analyzed were $\mathrm{pH}$ in water, calcium $(\mathrm{Ca})$, magnesium $(\mathrm{Mg})$, aluminum (Al), sulfur $(\mathrm{S})$, phosphorus (P- Mehlich), potassium $(\mathrm{K})$, copper $(\mathrm{Cu})$, zinc $(\mathrm{Zn})$, boron (Bo), iron $(\mathrm{Fe})$, manganese $(\mathrm{Mn})$, and sodium $(\mathrm{Na})$; acid potential $(\mathrm{Al}+\mathrm{H})$; base saturation $(\mathrm{S})$; base sum $(\mathrm{V})$; cation exchange capacity (CEC); organic matter (OM); and molar relations $[\mathrm{Ca} / \mathrm{Mg}] / \mathrm{K}$ and $\mathrm{K} /\left[(\mathrm{Ca} / \mathrm{Mg})^{1 / 2}\right]$. Granulometry of the fine fraction (\% sand, \% clay, and \% silt) was performed by the Laboratory of Soil Analysis of the Farroupilha Federal Institute, São Vicente Campus.

For the determination of the soil moisture, 50 samples were also collected at a depth of 0-20 cm using a cutting blade and volumetric rings. The thermo-gravimetric method was used for this analysis, which consisted of weighing the mass of a wet soil $(\mathrm{Mu})$, then drying it in an oven at $105-110{ }^{\circ} \mathrm{C}$ for $24 \mathrm{~h}$, and subsequently determining its dry mass (Ms). The analysis was performed at the Soil Laboratory of the Farroupilha Federal Institute, Alegrete Campus.

The canopy opening was determined by averaging four readings, toward the north, south, east and west, in the center of each $10 \mathrm{~m} \times 10 \mathrm{~m}$ plot at $1 \mathrm{~m}$ from the ground, using a convex spherical densiometer (CALLEGARO et al., 2017). The readings were taken in the month of March 2015 between 11 am and 1 pm under conditions of full sun and absence of clouds.

For the analysis of the tree structure, the density, frequency, dominance, and importance value were calculated, and for the analysis, the natural regeneration, density, frequency, size category (SC), and relative natural regeneration (RNR) were obtained. To calculate the RNR (\%), the arithmetic mean of the relative values of the abundance, frequency, and SC was used. To obtain the SC, the height classes for natural regeneration were established as follows: Class I: $10 \mathrm{~cm} \leq$ height $(\mathrm{h})<50 \mathrm{~cm}$; Class II: $50 \mathrm{~cm} \leq \mathrm{h}<100 \mathrm{~cm}$; Class III: $100 \mathrm{~cm} \leq \mathrm{h}$ $<150 \mathrm{~cm}$; Class IV: $150 \mathrm{~cm} \leq \mathrm{h}<200 \mathrm{~cm}$, and Class V: $\mathrm{h} \geq 200 \mathrm{~cm}$ and DBH $<5 \mathrm{~cm}$.

To test the formulated hypothesis that there are variations in the ordering of the species along the environmental gradient of an evaluated forest, the vegetation data of the tree bush and regenerating component were analyzed. This was done together with the data on the sampled environmental variables via canonical correspondence analysis (CCA). For the purpose of CCA, two matrices were built: matrix of species (MS) and environmental matrix (EM). The EM provided the abundance of the species that presented ten or more specimens in the sample. The species abundance values were transformed by the expression, $\log _{10}(a+1)$. Initially, the EM was formed by all the measured variables. Subsequently, some EM variables were removed because they were highly correlated $(r>0.9)$. In addition, the variables with weak correlations $(r<0.4)$ with the first two ordination axes were removed. The variables that presented extremely close vectors in the initial twodimensional map were also excluded, retaining in the analysis, the variables with the highest correlation with the ordination axes.

The final CCA of the tree bush component was performed with 100 plots, 12 species, and six environmental variables. The CCA of the Class I regenerating component was analyzed with 89 plots, 14 species, and five environmental variables, and that of Class II was performed with 96 plots, 11 species, and four environmental variables.

\section{RESULTS}

In the tree and bush components, the estimated density was 1,198 ind.ha ${ }^{-1}$, constituting 28 species distributed in 27 genera and 16 botanical families. In the regenerating component, the estimated density of the specimens in Class I was 17,975 ind.ha ${ }^{-1}$, comprising of 22 species distributed in 22 genera and 17 families. Moreover, the estimated density of the specimens in Class II was 4,148 ind.ha ${ }^{-1}$, constituting 18 species distributed in 18 genera and 13 families. Considering the tree and bush strata and regenerator, 30 species were found in total (Table 1).

In the tree bush structure of the evaluated forest, the total absolute dominance was $27.9 \mathrm{~m}^{2} . \mathrm{ha}^{-1}$, with the highest values recorded for Nectandra megapotamica $\left(6.69 \mathrm{~m}^{2} . \mathrm{ha}^{-1}\right)$, Ocotea acutifolia $(6,55)$, Pouteria salicifolia (4,53), and Allophylus edulis $(2,77)$, corresponding to $73,6 \%$ of the total species.

FLORESTA, Curitiba, PR, v. 49, n. 4, p. 773 - 782, out/dez 2019. 
Among the 28 sampled species, 22 had a value lower than $1 \mathrm{~m}^{2} / \mathrm{ha}^{-1}$ of the total basal area. The mean diameter obtained was $14.1 \mathrm{~cm}$, and the maximum diameter was $84.4 \mathrm{~cm}$; the latter being presented by the species, Ocotea pulchella. Among the 1,198 sampled specimens, $8.8 \%$ had branches at the stem base.

The relative importance values (RIVs) of species Ocotea acutifolia (18.5\%), Pouteria salicifolia (15.6\%), Nectandra megapotamica (13,1\%), Allophylus edulis (12.3\%), and Eugenia uniflora (8.5\%) presented the highest RIVs of the tree bush component (Table 1).

Tabela 1. Parâmetros fitossociológicos das espécies amostradas no componente regenerante e no componente arbóreo-arbustivo de uma floresta ribeirinha do bioma Pampa, Rio Grande do Sul. Sant'Ana do Livramento, RS. 2017.

Table 1. Phyto-sociological parameters of the sampled species in the arboreal stratum and natural regeneration in a riverine forest of the Pampa biome, Rio Grande do Sul. Sant'Ana do Livramento, RS. 2017.

\begin{tabular}{|c|c|c|c|c|c|c|}
\hline \multirow{3}{*}{ Species } & \multicolumn{3}{|c|}{ Natural Regeneration } & \multicolumn{3}{|c|}{$\begin{array}{c}\text { Arboro-Arbustive } \\
\text { Layer }\end{array}$} \\
\hline & \multicolumn{2}{|c|}{ AD (ind.ha ${ }^{-1}$ ) } & \multirow{2}{*}{$\begin{array}{c}\text { RNR } \\
(\%) \\
\end{array}$} & \multirow{2}{*}{$\begin{array}{c}\text { AD } \\
\left(\text { ind.ha }^{-1}\right)\end{array}$} & \multirow{2}{*}{$\begin{array}{c}\text { ADo } \\
\left(\mathbf{m}^{2} . \mathbf{h a}^{-1}\right)\end{array}$} & \multirow{2}{*}{$\begin{array}{l}\text { RIV } \\
(\%)\end{array}$} \\
\hline & CI & CII & & & & \\
\hline Allophylus edulis (A.St.-Hil. et al.) Hieron. ex Niederl. & 575 & 12 & $2.5^{\mathrm{a}}$ & 173 & 2.77 & $12 .^{3 a}$ \\
\hline Aloysia gratissima (Gillies \& Hook.) Tronc. & 75 & 112 & 1.4 & 11 & 0.03 & 0.7 \\
\hline Blepharocalyx salicifolius (Kunth) O.Berg & 2625 & 48 & $9.2^{\mathrm{a}}$ & 24 & 0.30 & $2.0^{\mathrm{a}}$ \\
\hline Calliandra tweedii Benth. & 750 & 4 & 2.1 & 1 & 0.00 & 0.1 \\
\hline Celtis iguanaea (Jacq.) Sarg. & 1950 & 204 & $8.5^{\mathrm{a}}$ & 21 & 0.07 & 1.5 \\
\hline Citharexylum montevidense (Spreng.) Moldenke & 425 & 20 & 1.8 & 4 & 0.15 & 0.5 \\
\hline Daphnopsis racemosa Griseb. & 25 & 0 & 0.1 & 0 & 0.00 & 0.0 \\
\hline Eugenia uniflora $\mathrm{L}$. & 4075 & 1980 & $27 .^{7 \mathrm{a}}$ & 139 & 0.79 & $8.5^{\mathrm{a}}$ \\
\hline Gymnanthes klotzschiana Müll. Arg. & 1250 & 52 & $5.3^{\mathrm{a}}$ & 110 & 1.42 & $8.0^{\mathrm{a}}$ \\
\hline Lithraea molleoides (Vell.) Engl. & 50 & 0 & 0.2 & 5 & 0.15 & 0.6 \\
\hline Matayba elaeagnoides Radlk. & 225 & 0 & 0.9 & 2 & 0.01 & 0.2 \\
\hline Maytenus muelleri Schw. & 50 & 0 & 0.2 & 0 & 0.00 & 0.0 \\
\hline Myrcia selloi (Spreng.) N. Silveira & 450 & 24 & 1.9 & 7 & 0.02 & 0.4 \\
\hline Myrcianthes pungens (O.Berg) D. Legrand & 125 & 0 & 0.5 & 6 & 0.64 & 1.2 \\
\hline Myrrhinium atropurpureum Schott & 1575 & 64 & $6.2^{\mathrm{a}}$ & 2 & 0.01 & 0.2 \\
\hline Nectandra megapotamica (Spreng.) Mez & 0 & 52 & 0.7 & 82 & 6.69 & $13 .^{1 \mathrm{a}}$ \\
\hline Ocotea acutifolia (Nees) Mez & 450 & 196 & $3.1^{\mathrm{a}}$ & 226 & 6.55 & $18^{5 \mathrm{a}}$ \\
\hline Ocotea pulchela (Ness \& Mart.) Mez & 0 & 0 & 0.0 & 15 & 1.51 & $2.8^{\mathrm{a}}$ \\
\hline Pouteria salicifolia (Spreng.) Radlk. & 525 & 588 & $8.4^{\mathrm{a}}$ & 202 & 4.53 & $15.6 \mathrm{a}$ \\
\hline Prunus myrtifolia (L.) Urb. & 0 & 0 & 0.0 & 8 & 0.27 & 1.0 \\
\hline Quillaja brasiliensis (A.St.-Hil. \& Tul.) Mart & 25 & 0 & 0.1 & 3 & 0.09 & 0.4 \\
\hline Ruprechtia laxiflora Meisn. & 0 & 0 & 0.0 & 2 & 0.16 & 0.3 \\
\hline Sebastiania brasiliensis Spreng. & 0 & 0 & 0.0 & 3 & 0.03 & 0.2 \\
\hline Schinus molle L. & 0 & 0 & 0.0 & 2 & 0.05 & 0.2 \\
\hline Schinus lentiscifolius Marchand & 0 & 20 & 0.2 & 6 & 0.06 & 0.3 \\
\hline Schinus polygamus & 0 & 0 & 0.0 & 6 & 0.43 & 1.0 \\
\hline Scutia buxifolia Reissek & 625 & 308 & $5.8^{\mathrm{a}}$ & 72 & 0.60 & $5.2^{\mathrm{a}}$ \\
\hline Styrax leprosus Hook. \& Arn. & 775 & 448 & $7.4^{\mathrm{a}}$ & 62 & 0.53 & $4.6^{\mathrm{a}}$ \\
\hline Xylosma tweediana (Clos) Eichler & 1225 & 12 & $4.7^{\mathrm{a}}$ & 1 & 0.00 & 0.1 \\
\hline Zanthoxylum rhoifolium Lam. & 125 & 4 & 0.7 & 3 & 0.04 & 0.3 \\
\hline Total & 17.975 & 4.148 & 100 & 1198 & 27.90 & 100 \\
\hline
\end{tabular}

$\mathrm{AD}=$ absolute density; $\mathrm{C}$ I: individuals with $10 \mathrm{~cm} \leq \mathrm{h}<1 \mathrm{~m}, \mathrm{C}$ II: $\mathrm{DBH}<5 \mathrm{~cm}$ and $\mathrm{h} \geq 1 \mathrm{~m}, \mathrm{RNR}=$ relative natural regeneration; $\mathrm{ADo}=$ absolute dominance; VI $=$ value of relative importance; ${ }^{\mathrm{a}}=$ species with high RNR or RIV. 
In Class I, the species, Eugenia uniflora (4.075 ind.ha $\left.{ }^{-1}\right)$, Blepharocalyx salicifolius $\left(2.625\right.$ ind.ha $\left.^{-1}\right)$, and Celtis iguanaea (1,950 ind.ha-1) had the highest absolute densities, contributing to $48.1 \%$ of the total sampled specimens. In Class II, the highest absolute densities were found for Eugenia uniflora $\left(1,980\right.$ ind.ha $\left.^{-1}\right)$, Pouteria salicifolia (588 ind.ha ${ }^{-1}$ ), and Styrax leprosus (448 ind.ha- ${ }^{-1}$ ), accounting for $72.7 \%$ of the sum of the specimens found.

The highest values of the RNR of the regenerating strata are presented by the following species (Table 1): Eugenia uniflora (27.7\%), Blepharocalyx salicifolius (9.2\%), Celtis iguanaea (8.5\%), Pouteria salicifolia $(8.4 \%)$, and Styrax leprosus $(7.4 \%)$.

The species, Pouteria salicifolia $(\mathrm{RIV}=15.6 \%$; RNR $=8.4 \%)$, Gymnanthes klotzschiana $(\mathrm{RIV}=8.0 \%$; $\mathrm{RNR}=5.3 \%)$, and Scutia buxifolia $(\mathrm{RIV}=5.2 \% ; \mathrm{RNR}=5.8 \%)$ have a high percentage of importance in the tree stratum (RIV) and a similar proportion in natural regeneration (RNR). However, in natural regeneration, Allophylus edulis $(\mathrm{RIV}=12.3 \% ; \mathrm{RNR}=2.5 \%)$ and Ocotea acutifolia $(\mathrm{RIV}=18.5 \%, \mathrm{RNR}=3.1 \%)$ show a decrease in the percentage of importance, but remain among the main regenerative species. Nevertheless, this is not observed for the species, Nectandra megapotamica $(\mathrm{RIV}=13.1 \% ; \mathrm{RNR}=0.7 \%)$ and Ocotea pulchella $(\mathrm{RIV}=$ $2.8 \%$; RNR $=0.0 \%)$. Unlike others, in natural regeneration, Myrrhinium atropurpureum $(\mathrm{RIV}=0.2 \% ; \mathrm{RNR}=$ $6.2 \%)$, Xylosma tweediana $(\mathrm{RIV}=0.1 \% ; \mathrm{RNR}=4.7 \%)$, Eugenia uniflora $(\mathrm{RIV}=8.5 \%) ; \mathrm{RNR}=27.74 \%)$, and Styrax leprosus $(\mathrm{RIV}=4.6 \%$; RNR $=7.4 \%$ ) exhibit an increase in the percentage of importance.

The results of the analysis of the physical and chemical parameters of the soil showed no variation in the textural class along the evaluated stretch of the riparian forest, which was classified as average. In bands $\mathrm{V}$, VI, VII, VIII, and IX, the sand content was higher in the plots closest to the stream, indicating the stretches where there was a decrease in the force in the stream, with a consequent deposition of thick sediments. In all the ranges, the organic matter content was generally average, and the saturation values of the bases and CEC indicated the presence of eutrophic soils. The $\mathrm{pH}$ value of the soil of the area was average, and in all the plots, the saturation by $\mathrm{Al}$ was extremely low. In relation to nutrients, deficiency was found only for P and B in plots 24 and 25 .

The CCA revealed the environmental variables that correlated with the distribution of the species in the tree bush component and natural regeneration (Table 2).

Tabela 2. Coeficientes de correlação entre as variáveis ambientais e os eixos de ordenação para espécies da estrutura arbórea-arbustiva e da regeneração natural de um trecho de floresta ribeirinha do bioma Pampa, Rio Grande do Sul. Sant'Ana do Livramento, RS. 2017.

Table 2. Correlation coefficients between the environmental variables and ordering axes for the arboreal component species and natural regeneration of a riparian forest section of the Pampa biome, Rio Grande do Sul. Sant'Ana do Livramento, RS. 2017.

\begin{tabular}{|c|c|c|c|c|c|c|}
\hline \multirow{4}{*}{ Environmental variables } & \multirow{2}{*}{\multicolumn{2}{|c|}{ Tree component }} & \multicolumn{4}{|c|}{ Natural regeneration } \\
\hline & & & \multicolumn{2}{|c|}{ Class I } & \multicolumn{2}{|c|}{ Class II } \\
\hline & Axis 1 & Axis 2 & Axis 1 & Axis 2 & Axis 1 & Axis 2 \\
\hline & \multicolumn{6}{|c|}{ Correlation } \\
\hline Cup opening & 0.441 & -0.142 & - & - & - & - \\
\hline Sand & -0.800 & 0.112 & -0.803 & -0.190 & 0.670 & 0.118 \\
\hline Clay & 0.603 & 0.563 & - & - & - & - \\
\hline Boron & - & - & 0.099 & -0.870 & - & - \\
\hline Calcium & - & - & - & - & -0.830 & -0.293 \\
\hline Altimetric Quota & - & - & -0.610 & -0.420 & - & - \\
\hline Organic Matter & 0.778 & 0.030 & - & - & -0.810 & 0.510 \\
\hline Depth of soil & -0.552 & -0.329 & - & - & - & - \\
\hline Litter & - & - & -0.528 & 0.342 & - & - \\
\hline Zinc & 0.668 & 0.205 & 0.628 & -0.040 & -0.673 & 0.000 \\
\hline
\end{tabular}

For the arboreal shrub component, the eigenvalues generated were low, 0.157 (axis 1) and 0.079 (axis 2), indicating the existence of short gradients; specifically, most species were distributed throughout the gradient, with some of them varying only in the abundance. The first two axes accounted for only $7.2 \%$ (axis 1 ) and $3.6 \%$ (axis 2) of the global variance of the data (cumulative total: 10.8\%), indicating much "noise" or unexplained 
remaining variance. Nevertheless, the significance of the species-environment relations was not impaired because the CCA yielded high species-environment correlations on the first two axes: 0.700 (axis 1) and 0.583 (axis 2).

The tree and bush layer ordination map (Figure 1) shows that the species, Pouteria salicifolia, Ocotea acutifolia, and Aloysia gratissima are positively located in relation to the crown opening (COPA) and organic matter (OM) present in the soil. This demonstrates that in the evaluated forest section, these species prefer soils with a high OM content and high exposure to light. Clay is positively correlated to the presence of Scutia buxifolia and Celtis iguanaea, indicating a large abundance of these species at the sites with a high clay content. Soil depth is another ecological conditioning factor of the tree and bush component, contributing to a larger abundance of the species, Nectandra megapotamica, Ocotea pulchella, Allophylus edulis, and Styrax leprosus. Sand favors the presence of Eugenia uniflora, Gymnanthes klotzschiana, and Blepharocalyx salicifolius in the studied section of the forest.

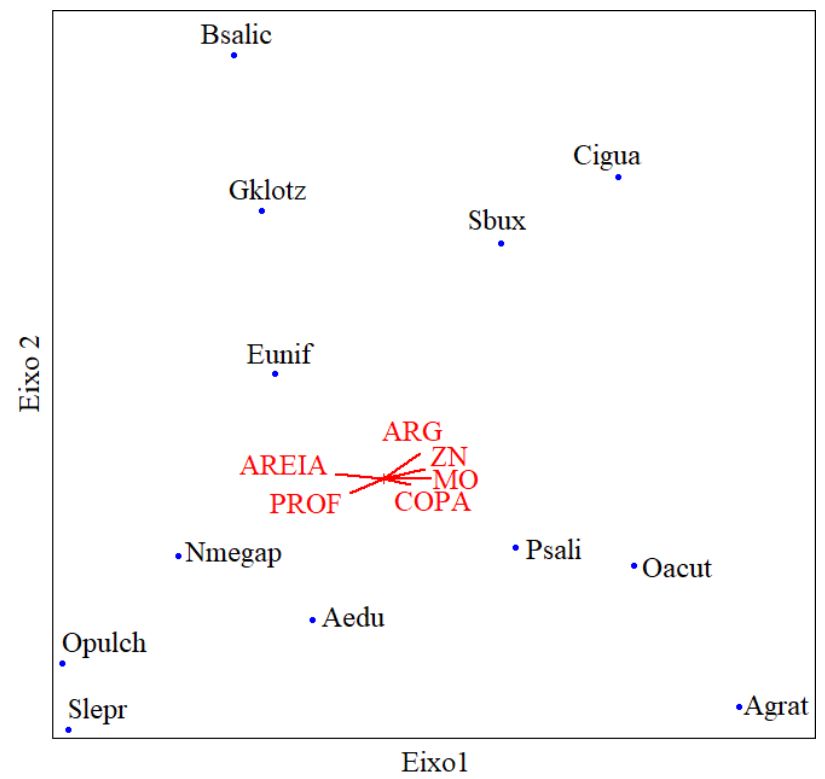

$\mathrm{ARG}=$ clay, $\mathrm{COPA}=$ crown opening, $\mathrm{DEP}=$ depth of soil, $\mathrm{OM}=$ organic matter, $\mathrm{ZN}=$ zinc.

Aedu: Allophylus edulis; Agrat: Aloysia gratissima; Bsalic: Blepharocalyx salicifolius; Cigua: Celtis iguanaea; Eunifl: Eugenia uniflora; Gklotz: Gymnanthes klotzschiana; Nmegap: Nectandra megapotamica; Oacut: Ocotea acutifolia; Opulch: Ocotea pulchella; Psali: Pouteria salicifolia; Sbux: Scutia buxifolia; Slepr: Styrax leprosus.

Figura 1. Diagrama de ordenação gerado pela CCA a partir da abundância de espécies no estrato arbóreoarbustivo e das variáveis ambientais de um trecho de floresta ribeirinha do bioma Pampa, Rio Grande do Sul. Sant'Ana do Livramento/RS. 2017.

Figure 1. Ordering diagram generated by the CCA from the abundance of the species in the arboreal stratum and the environmental variables of a riverine forest stretch of the Pampa biome, Rio Grande do Sul. Sant'Ana do Livramento/RS. 2017.

We observed in the CCA that the regenerative component eigenvalues and total variance were distinct from those of the arboreal shrub component (Class I: axis 1: 0.120 and var. $=4.0 \%$; axis 2: 0.070 and var. = 2.3\%; Class II: axis 1: 0.217 and var. $=7.0 \%$ and axis $2: 0.064$ and var. $=2.1 \%)$. The relations between the ordering of the samples based on the species and ordering based on the environmental variables were high (Class I: axis 1: 0.632 and axis 2: 0.519; Class II: axis 1: 0.623 and axis 2: 0.419).

In Class I of the regenerating component, axis 1 highlights that the species in the areas with a large accumulation of litter, high elevation, and high levels of sand are more abundant in the areas with a high content of zinc. Axis 2 indicates that the species in the lower portion of the ordination map are more abundant in the soils with a higher boron content (Figure 2A). In Class II of natural regeneration, it is found that axis 1 divides the species with a high abundance in the locations with a high content of organic matter, zinc, and calcium into areas with a high content of sand (Figure 2B).

Considering Class I of natural regeneration, it is clear that the species, Styrax leprosus, Calliandra tweedii, Myrcia selloi, and Pouteria salicifolia, are correlated to the thickness of the litter. The species, Allophylus edulis, prefers environments with high sand contents and high altimetry quota. High rates of zinc in 
soil favor the species, Ocotea acutifolia, Gymnanthes klotzschiana, Xilosma tweediana, Blepharocalyx salicifolius, and Eugenia uniflora. The abundance of Myrrhinium atropurpureum and Citharexylum montevidense is favored by the presence of high boron rates in the soil.
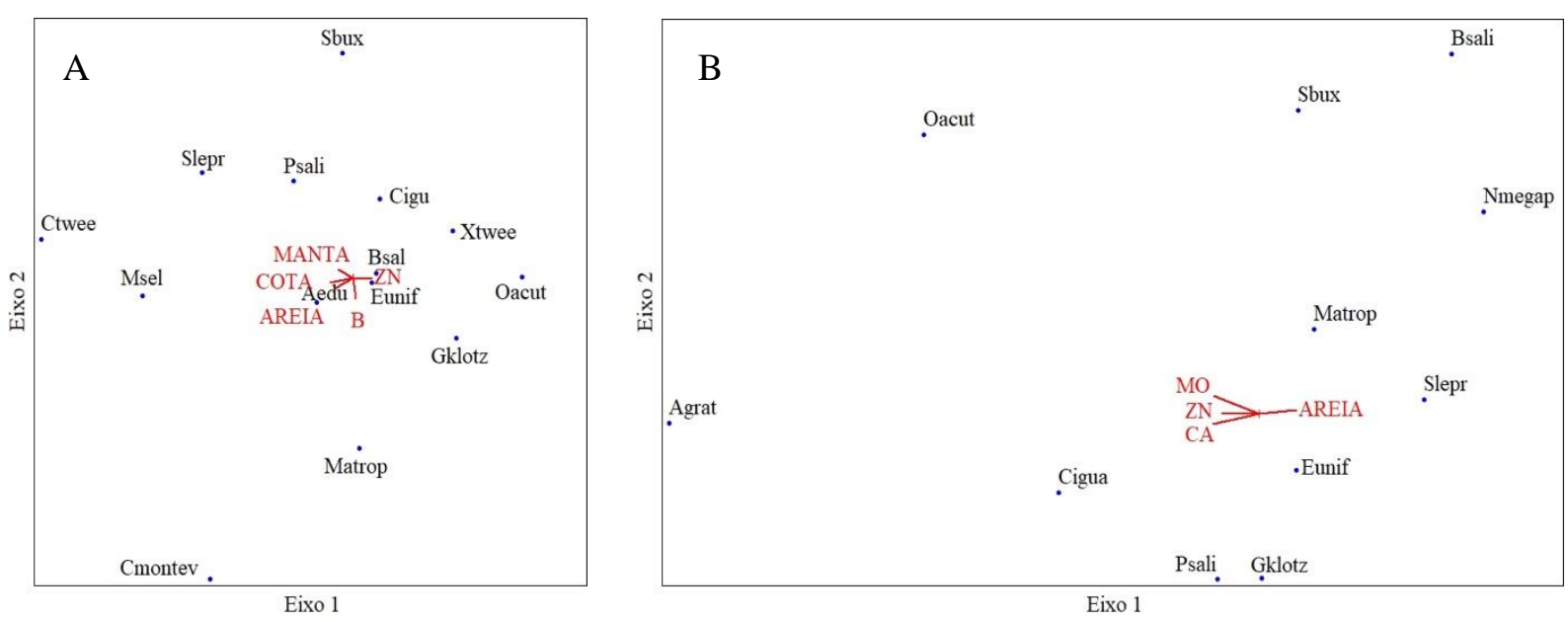

$\mathrm{B}=$ boronn; $\mathrm{CA}=$ calcium; COTA = spot elevation; MANTA = litter; $\mathrm{OM}=$ organic matter; $\mathrm{ZN}=$ zinc.

Aedu: Allophylus edulis; Agrat: Aloysia gratissima; Bsalic: Blepharocalyx salicifolius; Cigua: Celtis iguanaea; Cmontev: Citharexylum montevidense; Ctwee: Calliandra tweedii; Eunifl: Eugenia uniflora; Gklotz: Gymnanthes klotzschiana; Matrop: Myrrhinium atropurpureum; Msel: Myrcia selloi; Nmegap: Nectandra megapotamica; Oacut: Ocotea acutifolia; Psali: Pouteria salicifolia; Sbux: Scutia buxifolia; Slepr: Styrax leprosus; Xtwee: Xylosma tweediana.

Figura 2. Diagrama de ordenação gerados pela CCA a partir da abundância das espécies na regeneração natural Classe I (A) e Classe II (B) e das variáveis ambientais de um trecho de floresta ribeirinha no bioma Pampa, Rio Grande do Sul. Sant'Ana do Livramento/RS. 2017.

Figure 2. Ordering diagram generated by the CCA from the abundance of the species in natural regeneration Class I (A) and Class II (B) and the environmental variables of a stretch of a riverine forest in the Pampa biome, Rio Grande do Sul. Sant'Ana do Livramento/RS. 2017.

In ordering Class II of natural regeneration, it is noticed that the species, Ocotea acutifolia, Aloysia gratissima, Celtis iguanaea, and Pouteria salicifolia, correlate positively in the sites with high levels of organic matter, zinc, and calcium. High levels of sand correlate positively with the species Myrrhinium atropurpureum, Eugenia uniflora, Nectandra megapotamica, Blepharocalyx salicifolius, Scutia buxifolia, and Styrax leprosus.

\section{DISCUSSION}

In the regional context, the number of species recorded for the stretch of the evaluated riparian forest in the Espinilho stream can be considered as low when compared to other studies conducted in riparian forests in the region, for example, the Jacuí/Cachoeira do Sul river contains 49 species (ARAÚJO et al., 2004) and the Corrales/Minas de Corrales/Uruguay stream comprises of 32 species (PIAGGGIO \& DELFINO, 2009). This is within the expected range when compared to the work performed in the Botucarai//Cachoeira do Sul river, i.e., 30 species (BUDKE et al., 2007) in the Camaquã/Cristal river: 29 species (DE MARCHI \& JARENKOW, 2008) and in the Ibirapuitã/Sant'Ana do Livramento river, i.e., 23 species (OLIVEIRA et al., 2015). However, it is necessary to consider that there are singularities in the richness of the species and structure of the forest communities owing to the influence of factors such as the history of the use of the area, soil, and topographic conditions, among others (SCIPIONI et al., 2009). Furthermore, in riparian environments, the low diversity in the riparian forests is mainly owing to the water stress to which the species are subjected (RODRIGUES \& SHEPHERD, 2009; DE MARCHI \& JARENKOW, 2008). Therefore, the floristic composition in young forest communities is a representation of the local colonization patterns of the species and effects of the remaining vegetation (CHAZDON et al., 2007).

The total density of the specimens per sampled area of the tree component $\left(1,198\right.$ ind.ha $\left.^{-1}\right)$ is in an intermediate range relative to the densities obtained in the other riverside forest formations of the state. It is lower than those estimated by Araujo et al. (2016) for a stretch of riverine forest of the Espinilho stream without the presence of cattle $\left(1,456\right.$ in.ha $\left.{ }^{-1}\right)$ and by De Marchi and Jarenkow (2008) for the Camaquã river forest $(2,179$ in.ha $\left.{ }^{-1}\right)$. Contrastingly, it is higher than those obtained by Oliveira et al. (2015) for the Ibirapuitã river (816.47 
in.ha $\mathrm{a}^{-1}$ ) and by Araujo et al. (2016) for the riverside forest of the Espinilho stream in the presence of cattle $\left(1,058.3\right.$ ind.ha $\left.^{-1}\right)$.

The absolute dominance value obtained is considered to be lower than that recorded in other riverside forests of the state; for example, for the Jacuí/Cachoeira do Sul river it was 29.6/30.6/29.83 $\mathrm{m}^{2}$. ha $^{-1}$ (ARAÚJO et al., 2004), for the Piratini/Arroio Grande river it was $46.26 / 40.10 \mathrm{~m}^{2} . \mathrm{ha}^{-1}$ (KILCA et al., 2012), and for the Camaquã/Cristal river it was $40.107 \mathrm{~m}^{2}$.ha ${ }^{-1}$ (DE MARCHI \& JARENKOW, 2008). In comparison, the absolute dominance value is higher than that found for the Jacuí river, i.e., $19.93 \mathrm{~m}^{2} . \mathrm{ha}^{-1}$ (LONGHI et al., 1982), Jacuí/Cachoeira do Sul river, i.e., $23.31 \mathrm{~m}^{2} . \mathrm{ha}^{-1}$ (LINDEMAIER \& BUDKE, 2006), river Botucaraí/Cachoeira do Sul, i.e., $24.85 \mathrm{~m}^{2}$.ha-1 (BUDKE et al., 2007), and Corrales/Minas de Corrales/Uruguay stream, i.e., 14.52 $\mathrm{m}^{2}$.ha ${ }^{-1}$ (PIAGGGIO \& DELFINO, 2009). Oliveira et al. (2015) when studying the riverine forest of the Ibirapuitã river in the municipality of Sant'Ana do Livramento, determined an absolute dominance of $40.7 \mathrm{~m}^{2} . \mathrm{ha}^{-}$ ${ }^{1}$, a value higher than that found in this research. The researchers attributed the high dominance value to the high number of branched specimens $(50.28 \%$ of specimens were branched).

Species with high RIV cited in the survey, Pouteria salicifolia, Ocotea acutifolia, Eugenia uniflora, and Gymnanthes klotzschiana, were also among the top ten species of the tree component in other riparian forests of Rio Grande do Sul and the Department of Rivera, Uruguay (PIAGGGIO \& DELFINO, 2009; GRELA, 2003; OLIVEIRA et al., 2015). The pedological and geomorphological variables combined with other variables such as light and temperature also influence the density and dominance of the species in the tree stratum (JUNIOR FERREIRA et al., 2012; CALLEGRO et al., 2017). Ocotea acutifolia (226 specimens ha ${ }^{-1}$ ), Pouteria salicifolia (202), Allophylus edulis (173), and Eugenia uniflora (139), which exhibited a high density were, according to Kilca et al. (2012), zoochoric species. The following dispersion strategy may have been a positive aspect in increasing the density of the species: the leaving of their seeds in environments with favorable ecological conditions for their development. Seed dispersal is an essential factor for the colonization of habitats and constitution of the spatial and temporal structures of plant populations, and it may have a profound effect on the dynamics, structure, and composition of forest communities (BARBOSA et al., 2012).

Comparing the results of the densities of the arboreal shrub and regenerating component of the studied riverside forest, it can be seen that the species, Ocotea acutifolia, which most characterizes the adult forest, differs from the regenerating stratum, where it is the twelfth in Class I and sixth in Class II.

Daphnopsis racemosa (shade-tolerant shrub) and Celtis iguanaea (light-demanding shrub), small species but with different luminosity requirements, are noted to adapt to the lower layer of the forest. This scenario shows that there are highly shaded environments in the forest suitable for species that are tolerant to shade as well as environments of high luminosity, favorable to the growth of species that require light.

It is noteworthy that certain particularities such as the high density of specimens and existence of species of arboreal shrub habits with expressive RNR in the regenerating component indicate the importance of this component for the ecosystem.

The results of RIV and the RNR reveal that some species in the tree and bush stratum maintain a similar pattern in natural regeneration. The high density of the regenerative component observed for the species, Eugenia uniflora and Styrax leprosus, can be attributed to the lack of limiting factors and ease of dispersion of the diasporas because they are zoochoric species (LEYSER et al., 2012).

For the occurrence of some species of the tree bush component, such as Pouteria salicifolia and Ocotea acutifolia, the sunlight factor and soil chemical factors are more crucial. However, species such as Nectandra megapotamica, Allophylus edulis, and Gymnanthes klotzschiana respond more directly to the soil texture aspects. Under the riparian condition, the soil physical factors, determined directly by the local hydrological behavior, condition the distribution and composition of species more in contrast to the chemical factors of the sediment, which are only indirectly determined by the dynamics of the river (RODRIGUES \& SHEPHERD, 2009).

Ocotea acutifolia and Pouteria salicifolia, species that are noticeable in the analysis as sociologically more important, present a higher abundance in soils with richer organic matter and more exposure to sunlight. For the riverine forest of the Ibirapuitã river, Pouteria salicifolia was referred to as the most sociologically important species in soils rich in organic matter (OLIVEIRA et al., 2015). Note that the latter is one of the few works of this nature performed in the Pampa biome in the region of Campanha.

Nectandra megapotamica and Allophylus edulis have a larger abundance of specimens in locations with a higher soil depth. Oliveira et al. (2015) associated Allophylus edulis with the $\mathrm{pH}$ value and base saturation. The same species was also related to these parameters for the Botucaraí river forest (BUDKE et al., 2007).

In general, the regenerating component presents an order influenced by the physical and chemical characteristics of the soil, elevation, organic matter, and thickness of the litter. Generally, young tree communities are influenced by the biotic and abiotic conditions along the successional and topographic gradients (SANAPHRE-VILLANUEVA et al., 2016). 
It may be seen that the soil attributes condition the natural regeneration in both Class I and Class II in the assessed stretch of the forest. Higuchi et al. (2015) and Scipioni et al. (2009) highlighted the importance of the degree of soil development for the regenerating component in a fragment of mixed montane ombrophylous forest in the Santa Catarina plateau and in a deciduous seasonal forest in the central region of Rio Grande do Sul.

The findings of this research corroborate the importance of environmental variables in the dispersion process. It is found that the overall variance of the data of Class I plants $(6.3 \%)$ is lower than that observed for Class II/established regeneration $(9.1 \%)$ and arboreal bush layer $(10.8 \%)$, with a tendency to increase the cumulative effect of the environmental variables as the tree ontogeny advances.

\section{CONCLUSIONS}

- In general, species in the tree and bush stratum did not maintain the same density pattern in the regenerating stratum;

- the soil and canopy opening characteristics had a tremendous influence on the species of the tree and bush structure;

- the soil characteristics, thickness of the serapiheira organic matter, and elevation had a significant influence on the species in natural regeneration.

\section{ACKNOWLEDGEMENTS} collection

The authors thank Helio Lima Araujo and Maria Martina Bentancor Araujo for their assistance in data

\section{BIBLIOGRAPHICAL REFERENCES}

ARAujO, A. B. C.; ARAujO, H. J., B., A.; CAllegARO, R. M.; ANDRZEJEWSKI, C.; LONGHI, S., J. Estrutura de dois componentes arbóreos de Floresta Subtropical Ripária na Campanha Gaúcha, Sant'ana do Livramento, RS. Floresta, Curitiba, v. 46, n. 4, p. 481-490, 2016.

ARAÚJO, M. M.; LONGHI, S. J.; BRENA, D. A.; BARROS, P. L. C. de; FRANCO, S. Análise de agrupamento da vegetação de um fragmento de Floresta Estacional Decidual Aluvial, Cachoeira do Sul, RS, Brasil. Ciência Florestal, Santa Maria, v. 14, n. 1, p. 133- 147, 2004.

BUDKE, J. C.; JARENKOW, J. A.; OLIVEIRA-FILHO, A. T. Relationships between tree componet structure, topography and soils of a riverside forest, Rio Botucaraí, Southern Brazil. Plant Ecology, New York, v. 189, p. 187-200, 2007.

BUDKE, J. C.; JARENKOW, J. A; OLIVEIRA-FILHO, A. T. de. Intermediary disturbance increases tree diversity in riverine forest of southern Brazil. Biodiversity and Conservation, Switzerland, v. 19, n. 8, p. 2371$2387,2010$.

BYNG, J. W.; CHASE, M. W.; CHRISTENHUSZ, M. J. M.; FAY, M. F.; JUDD, W. S.; MABBERLEY, D. J.; SENNIKOV, A. N.; SOLTIS, D. E.; SOLTIS, P. S.; STEVENS, P. F.. An update of the Angiosperm Phylogeny Group classification for the orders and families of flowering plants: APG IV. Botanical Journal of the Linnean Society, London, v. 181, n.1, p. 1-20. 2016

CALlEGARO, R. M.; ARAUJO, M. M.; LONGHI, S. J.; ANDRZEJEWSKI, C.; TURCHETTO, F.; GOMES, D. R. Fitossociologia e fatores ecológicos da vegetação estacional na região central do Rio Grande do Sul, Brasil. Iheringia: Série Botânica, Porto Alegre, v. 72, n. 1, p. 33-43, 2017.

CHAZDON, R. L.; LETCHER, S. G.; BREUGEL, M. van; MARTÍNEZ-RAMOS, M.; BONGERS, F.; FINEGAN, B. Rates of change in tree communities of secondary Neotropical forests following major disturbances. Philosofical Transactions of the Royal Society B: Biological Sciences, Londres, v. 362, n. 2, p. 273-289, 2007.

DE MARCHI, T. C.; JARENKOW, J. A. Estrutura do componente arbóreo de mata ribeirinha no rio Camaquã, município de Cristal, Rio Grande do Sul, Brasil. Iheringia: Série Botânica, Porto Alegre, v. 63, n. 2, p. 241$248,2008$.

FERREIRA JÚNIOR, W. G.; SCHAEFER, C. E. G. R.; SILVA, A. F. Uma visão pedogeomorfológica sobre as formações florestais da Mata Atlântica. In: MARTINS, S. V. Ecologia de florestas tropicais do Brasil. Viçosa: Ed. UFV, 2012, 371p. 
GRELA, I. Evaluación del estado sucesional de un bosque subtropical de quebradas en el norte de Uruguay. Acta Botanica Brasilica, Belo Horizonte, v. 17, n. 2, p. 315-324, 2003.

HIGUCHI, P.; SILVA, A. C. da; BUZZI JUNIOR, F.; NEGRINII, M.; FERREIRA, T. de S.; SOUZA, S. T. de; SANTOS, K. F. dos; VEFAGO, M. B. Fatores determinantes da regeneração natural em um fragmento de floresta com araucária no planalto catarinense. Scientia Forestalis, Piracicaba, v. 43, n. 106, p. 251-259, 2015.

KILCA, R. V.; SOARES, J. C. W.; SOUZA, A. M.; MEDEIROS, E. M. de; JARENKOW, J. A. Cambios florísticos y estructurales entre dos comunidades arbóreas de um bosque ripário bajo condiciones ambientales contrastantes en la Pampa sur brasileña. Iheringia: Série Botânica, Porto Alegre, v. 67, n. 2, p. 165-175, 2012.

LEYSER, G.; ZANIN, E. M.; BUDKE, J. C.; MÉLO, M. A. de; HENKE-OLIVEIRA, C. Regeneração de espécies arbóreas e relações com componente adulto em uma floresta estacional no vale do rio Uruguai, Brasil. Acta Botanica Brasilica, Belo Horizonte, v. 26, n. 1, p. 74-83, 2012.

LONGHI, S. J.; DURLO, M. A.; MARCHIORI, J. N. C. A vegetação da mata ribeirinha no curso médio do rio Jacuí, RS. Ciência e Natura, Santa Maria, v. 4, p. 151-161, 1982.

MARCHESINI, V. A., SALA, O. E.; AUSTIN, A. T. Ecological consequences of a massive flowering event of bamboo (Chusquea culeou) in a temperate forest of Patagonia, Argentina. Journal of Vegetation Science, Hoboken, n. 20, n. 3, p. 424-432, 2009.

MATZENAUER, R.; RADIN, B.; ALMEIDA, I. R. de (Ed.). Atlas Climático: Rio Grande do Sul. Porto Alegre: Secretaria da Agricultura Pecuária e Agronegócio; Fundação Estadual de Pesquisa Agropecuária (FEPAGRO), 2011.

OLIVEIRA, M. de L. A.; GRINGS, M.; RICHTER, F. S.; BACKES, A. R. Composição, estrutura e fatores edáfico condicionantes da distribuição das espécies do componente arbóreo em floresta ribeirinha do rio Ibirapuitã, Bioma Pampa. Iheringia: Série Botânica, Porto Alegre, v. 70, n. 2, p. 245-263, 2015.

PIAGGIO, M.; DELFINO, L. Florística y fitosociología de un bosque fluvial en Minas de Corrales, Rivera, Uruguay. Iheringia: Série Botânica, Porto Alegre, v. 64, n. 1, p. 45-51, 2009.

RODRIGUES, R. R. Uma discussão nomenclatural das formações ciliares. In: RODRIGUES, R. R.; LEITÃO FILHO, H. F. (Eds.). Matas ciliares: conservação e recuperação. São Paulo: Universidade de São Paulo, 2009, 320 p.

RODRIGUES, R. R.; SHEPHERD, G. J. Fatores condicionantes da vegetação ciliar. In: RODRIGUES, R. R.; LEITÃO FILHO, H. F. (Eds.). Matas ciliares: conservação e recuperação. São Paulo: Universidade de São Paulo, 2009, 320p.

SANAPHRE-VILlANUEVA, L.; DUPUY, J. M.; ANDRADE, J. L.; REYES-GARCIA, C.; PAZ, H.; JACKSON, P. C. Functional diversity of small and large trees along secondary succession in a tropical dry forest. Forests, Switzerland,v. 7, n. 8, p.1-15, 2016.

SCIPIONI, M. C.; LONGHI, S. J.; ARAUJO. M. M.; REINERTI, D. J. Regeneração natural de um fragmento da Floresta Estacional Decidual na Reserva Biológica do Ibicuí-Mirim (RS). Floresta, Curitiba, v. 39, n. 3, p. 675690, 2009

Silva, W. C.; MARANGON, L. C.; FERREIRA, R. L. C.; FEliCIANO, A. L. P.; APARÍCIO, P. da S.; COSTA JUNIOR, R. F.et al. Estrutura horizontal e vertical do componente arbóreo em fase de regeneração natural na mata Santa Luzia, no município de Catende-PE. Revista Árvore, Viçosa, v. 34, n. 5, p. 863-869, 2010.

STRECK, E. V.; KÄMPF, N.; DALMOLIN, R. S. D.; KLAMT, E.; NASCIMENTO, P. C. do; SCHNEIDER, P.. Solos do Rio Grande do Sul. Empresa de Assistência Técnica e Extensão Rural do Rio Grande do Sul/Associação Sulina de Crédito e Assistência Rural. Porto Alegre, 2 ed., 2008. 222p.

VÉLEZ, E.; CHOMENKO, L.; SCHAFFER, W.; MADEIRA, M.. Um panorama sobre as iniciativas de conservação dos Campos Sulinos. In PILlAR, V. P.; MÜllER, S. C., CASTILHOS, Z. M. S.; JACQUES, A. V. A. Campos Sulinos: conservação e uso sustentável da biodiversidade. Ministério do Meio Ambiente, Brasília, 2009. 453p. 